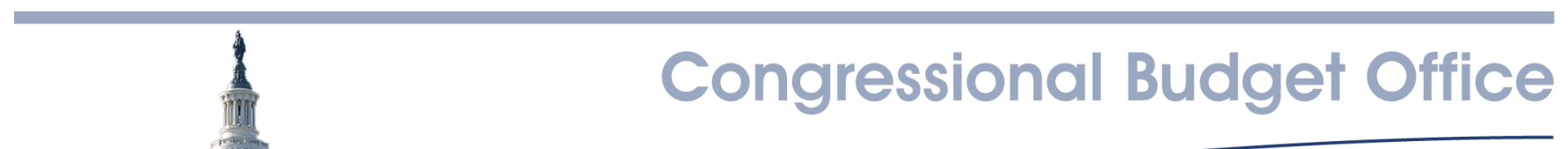

APRIL 2012

\title{
The Supplemental Nutrition Assistance Program
}

The Supplemental Nutrition Assistance Program (SNAP, formerly known as Food Stamps) provides benefits to low-income households to help them purchase food. The program is an "automatic stabilizer," meaning that its number of beneficiaries and amount of spending increase automatically during tough economic times. In fiscal year 2011, total federal expenditures on SNAP — \$78 billion-and participation in the program (measured as the number of participants and as a share of the U.S. population) were the highest they have ever been. In an average month that year, nearly 45 million people (or one in seven U.S. residents) received SNAP benefits (see Figure 1).

The number of people receiving SNAP benefits increased by almost 50 percent between fiscal years 2001 and 2005 and even more rapidly (by 70 percent) between fiscal years 2007 and 2011. During that latter period, spending on SNAP benefits grew by about 135 percent. The increase in the number of people eligible for and receiving benefits between 2007 and 2011 has been driven primarily by the weak economy. That increase was responsible for about 65 percent of the growth in spending on benefits between 2007 and 2011. About 20 percent of the growth in spending can be attributed to temporarily higher benefit amounts enacted in the American Recovery and Reinvestment Act of 2009 (ARRA). The remainder stemmed from other factors, such as higher food prices and lower income among beneficiaries, both of which boost benefits.

According to the Congressional Budget Office's (CBO's) March 2012 projections, the number of people who receive SNAP benefits will continue to rise slightly from fiscal year 2012 through fiscal year 2014, then decline in the following years. By fiscal year 2022, CBO projects, 34 million people (or about 1 in 10 U.S. residents) will receive SNAP benefits each month (roughly the same as the number in 2009), and SNAP expenditures, at about
$\$ 73$ billion, will be among the highest of all non-healthrelated federal support programs for low-income households.

In considering the future of the program, some policymakers might want to scale it back as part of a larger effort to reduce federal spending. Others might want to expand it to provide more assistance to people or to boost the economy in the short term. ${ }^{1}$ The current program could be changed by modifying eligibility rules, benefit amounts, administrative procedures, or other program activities, or by converting SNAP to a block grant program.

\section{Characteristics of SNAP Recipients}

In fiscal year 2010, the most recent year for which detailed demographic data are available, about threequarters of households receiving SNAP benefits included a child, a person age 60 or older, or a disabled person. ${ }^{2}$ Because households with children tend to be larger, they are likely to receive higher benefits than households without children. The average household receiving benefits consisted of 2.2 people. About half of all households receiving benefits were single-person households. ${ }^{3}$

1. See Congressional Budget Office, Options for Responding to ShortTerm Economic Weakness (January 2008), p. 6.

2. SNAP benefits are awarded to so-called food assistance units, which are generally equivalent to households and will be referred to as such in this analysis. A food assistance unit is a group of people living together-no familial relationship is required-and sharing the purchase, preparation, and consumption of food.

3. Esa Eslami, Kai Filion, and Mark Strayer, Characteristics of Supplemental Nutrition Assistance Program Households: Fiscal Year 2010 (report submitted by Mathematica Policy Research to the Department of Agriculture, Food and Nutrition Service, Office of Research and Analysis, September 2011), www.fns.usda.gov/ora/ menu/Published/snap/SNAPPartHH.htm. 


\section{Figure 1.}

\section{SNAP Participation and the Unemployment Rate, by Fiscal Year}

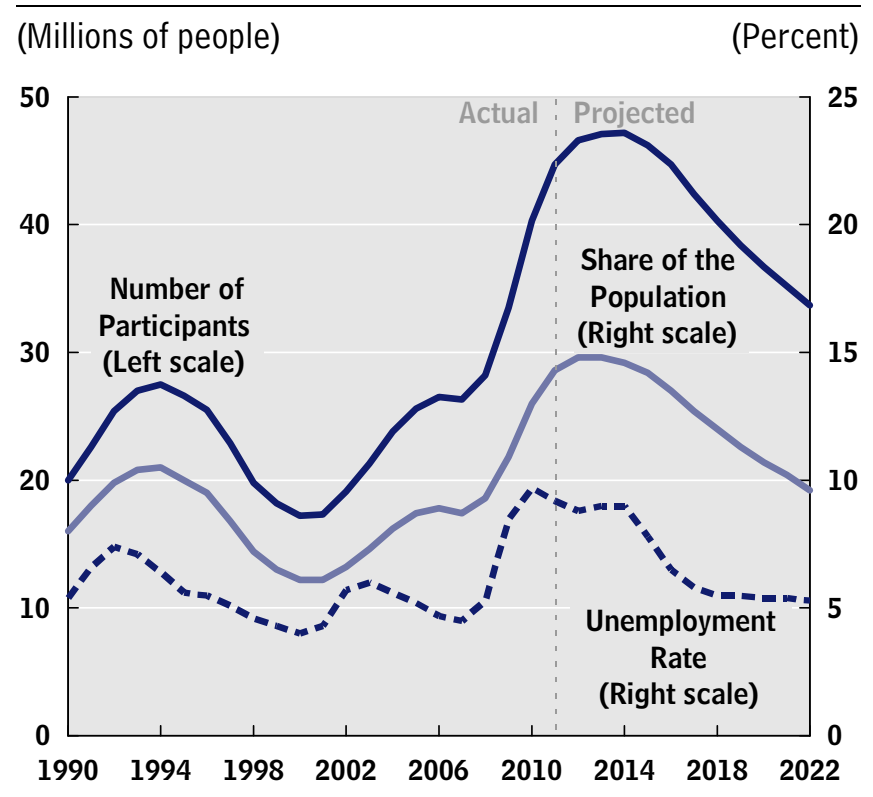

Source: Congressional Budget Office.

Notes: Data are annual. CBO's projections are from its March 2012 baseline.

SNAP = Supplemental Nutrition Assistance Program.

Most people receiving SNAP benefits live in households with very low income. In fiscal year 2010, 85 percent of households receiving benefits had income (excluding SNAP benefits) below the federal poverty guideline (about $\$ 18,500$ per year for a household of three). About 30 percent of recipient households reported earned income, and about 60 percent of households reported receiving unearned income from sources including the Supplemental Security Income (SSI) program, Social Security, and the Temporary Assistance for Needy Families (TANF) program (see Table 1). (Some households received both earned and unearned income.)

Over time, the share of SNAP households with earned income and the share with no income have both risen, whereas the share receiving cash assistance from Aid to Families with Dependent Children (AFDC) or its successor, TANF, has declined significantly. In 1990, just under 20 percent of SNAP households had earned income, and fewer than 10 percent reported no income. In 2010, in contrast, the share of households with earned income was roughly 30 percent, and about 20 percent of households reported having no income. In that year, less than 10 percent of households were receiving cash assistance from TANF, compared with more than 40 percent that were receiving cash assistance in 1990 from AFDC. Some of the increase in the share of households with earned income probably occurred because of changes in SNAP's rules and operation that made it easier for people who work to participate in the program. ${ }^{4}$ Most of the decline in the share of households receiving SNAP benefits that also received cash assistance was because of an overall reduction in the number of households receiving such assistance.

SNAP benefits represent a significant supplement to income for many households. The average household receiving SNAP benefits in 2010 had an income of $\$ 731$ per month (excluding the value of SNAP benefits), or about $\$ 8,800$ per year (see Table 1 ). The monthly SNAP benefit per household averaged $\$ 287$, or $\$ 4.30$ per person per day. On average, SNAP benefits boosted gross monthly income by 39 percent for all participating households and by 45 percent for households with children.

People who receive benefits tend to increase their total spending on food. Also, the receipt of SNAP benefits frees up resources that people can use to purchase other items and services. ${ }^{5}$ Recent evidence suggests that food security (defined as having access to adequate food for active healthy living) increases in households when they begin receiving benefits. ${ }^{6}$ Participation in SNAP may have other consequences for recipients, such as effects on health or nutrition, but evidence has so far been

4. Caroline Ratcliffe, Signe-Mary McKernan, and Kenneth Finegold, The Effect of State Food Stamp and TANF Policies on Food Stamp Program Participation (Washington, D.C.: Urban Institute, 2007), www.urban.org/publications/411438.html.

5. Mary Kay Fox, William Hamilton, and Biing-Hwan Lin, Effects of Food Assistance and Nutrition Programs on Nutrition and Health: Volume 3, Literature Review, Food Assistance and Nutrition Research Report No. 19-3 (Department of Agriculture, Economic Research Service, October 2004), www.ers.usda.gov/Publications/ FANRR19-3.

6. Mark Nord and Anne Marie Golla, Does SNAP Decrease Food Insecurity? Untangling the Self-Selection Effect, Economic Research Report No. 85 (Department of Agriculture, October 2009), www.ers.usda.gov/publications/err85. 
Table 1.

Characteristics of SNAP Households, Fiscal Year 2010

\begin{tabular}{|c|c|c|c|c|}
\hline & \multicolumn{2}{|c|}{ Participating Households } & \multirow{2}{*}{$\begin{array}{c}\text { Average Gross } \\
\text { Monthly Income } \\
\text { (Dollars) }\end{array}$} & \multirow{2}{*}{$\begin{array}{l}\text { Average Monthly } \\
\text { SNAP Benefit } \\
\text { (Dollars) }\end{array}$} \\
\hline & $\begin{array}{c}\begin{array}{c}\text { Number } \\
\text { (Millions) }^{\mathrm{a}}\end{array} \\
\end{array}$ & Percent $^{a}$ & & \\
\hline \multicolumn{5}{|l|}{ Households with Different Types of People } \\
\hline With children & 8.9 & 49 & 923 & 419 \\
\hline With people age 60 or older & 2.9 & 16 & 813 & 144 \\
\hline With disabled people age 59 or younger & 3.6 & 20 & 946 & 219 \\
\hline $\begin{array}{l}\text { Without children, people age } 60 \text { or older, } \\
\text { or disabled people }\end{array}$ & 4.3 & 24 & 268 & 194 \\
\hline \multicolumn{5}{|l|}{ Households with Different Types of Income } \\
\hline Earned income & 5.5 & 30 & 1,174 & 343 \\
\hline No earned income & 12.9 & 70 & 542 & 263 \\
\hline Unearned income & 11.1 & 60 & 858 & 265 \\
\hline Social Security income & 3.9 & 21 & 948 & 164 \\
\hline Supplemental Security Income & 3.8 & 21 & 863 & 212 \\
\hline TANF income & 1.5 & 8 & 719 & 428 \\
\hline No income ${ }^{b}$ & 3.6 & 20 & 0 & 297 \\
\hline All Households & 18.4 & 100 & 731 & 287 \\
\hline
\end{tabular}

Source: Congressional Budget Office based on Esa Eslami, Kai Filion, and Mark Strayer, Characteristics of Supplemental Nutrition Assistance Program Households: Fiscal Year 2010 (report submitted by Mathematica Policy Research to the Department of Agriculture, Food and Nutrition Service, Office of Research and Analysis, September 2011).

Note: SNAP = Supplemental Nutrition Assistance Program; TANF = Temporary Assistance for Needy Families.

a. Sum of household types does not match the total because a household can appear in more than one category. For example, a household could include both a child and a person age 60 or older.

b. Households with no income report $\$ 0$ gross income. Gross income includes most cash income (such as earnings, Social Security income, Supplemental Security Income, and TANF income) and excludes most noncash income and in-kind benefits.

inconclusive. ${ }^{7}$ In addition, receipt of SNAP benefits may reduce some people's incentive to work or their willingness to ask for help from family members or informal community networks, although research on those effects over the past 10 to 20 years is scant.

\section{SNAP Participation and Economic Conditions}

The number of people receiving SNAP benefits varies in response to changes in economic conditions. Even without new legislation, the number of beneficiaries rises noticeably during economic downturns. Then, as people's economic situation subsequently improves, some

7. Fox, Hamilton, and Lin, Effects of Food Assistance and Nutrition Programs on Nutrition and Health. participants leave the program and fewer new households enroll. Nevertheless, participation following an economic downturn does not always drop back to the level experienced before the downturn.

Between 1990 and 2011, the number of SNAP participants increased during periods of relatively high unemployment (see Figure 1). Even as the unemployment rate began to decline from its 1992, 2003, and 2010 peaks, decreases in participation typically lagged improvement in the economy by several years. For example, the number of SNAP participants rose steadily from about 20 million in the fall of 1989 to more than 27 million in April 1994-nearly two years after the unemployment rate began to fall and a full three years after the official end of the recession in March 1991. The number of people receiving SNAP benefits began to climb again in 2001 and continued to grow until 2006, 


\section{Figure 2.}

\section{SNAP Spending, by Fiscal Year}

(Billions of dollars)

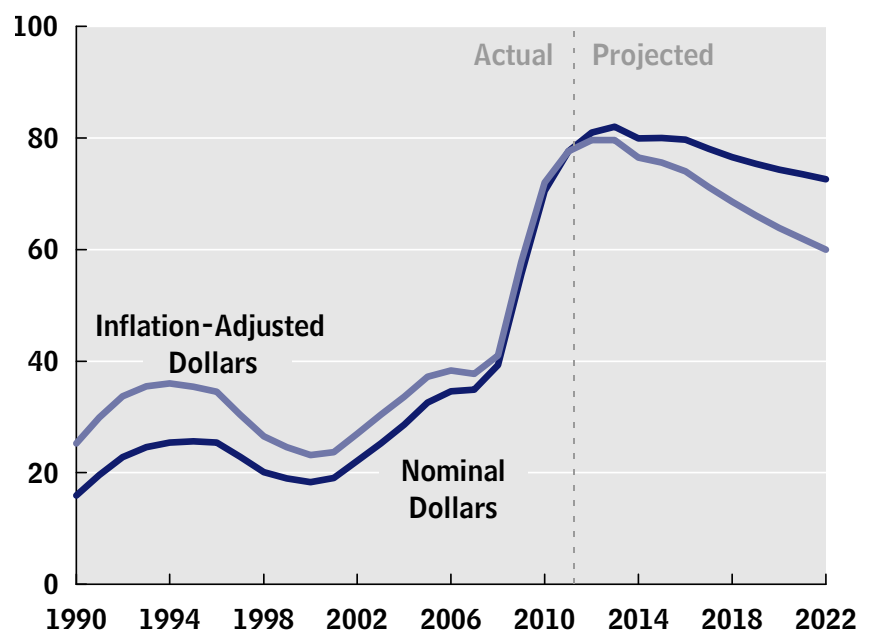

Source: Congressional Budget Office.

Notes: Data are annual. CBO's projections are from its March 2012 baseline. Spending is adjusted for inflation to fiscal year 2011 dollars using the price index for personal consumption expenditures.

SNAP $=$ Supplemental Nutrition Assistance Program.

more than two years after the unemployment rate began to decline and well after that recession ended (in November 2001). The number of participants temporarily leveled off in 2006 and 2007 until the unemployment rate began to rise sharply in 2008. Participation then started to grow quickly and has continued to increase since then.

\section{Why Have SNAP Participation and Spending Increased So Much Since 2007?}

Between 2007 and 2011, the number of people receiving SNAP benefits and federal spending on the program increased significantly (see Figures 1 and 2). On average, 45 million people (or about one in seven residents in the United States) received SNAP benefits each month in fiscal year 2011. That number represents a dramatic increase over the roughly 26 million people (or 1 of every 11) who received benefits in 2007 . The primary reason for the increase in the number of participants was the deep recession from December 2007 to June 2009 and the subsequent slow recovery; there were no significant legislative expansions of eligibility for the program during that time.

\section{Participation}

Between 2007 and 2011, both the number of people eligible for SNAP and the rate at which eligible people claimed benefits increased. Labor market conditions deteriorated dramatically between 2007 and 2009 and have been slow to recover: The unemployment rate jumped from 4.6 percent in 2007 to 9.6 percent in 2010 and was still at 8.5 percent at the end of 2011. The number of people eligible for the program increased by an estimated 20 percent from 2007 to 2009 (the latest year for which such data are available) and probably at an even faster rate from 2009 to 2011 . $^{8}$

Moreover, in 2009, 72 percent of people estimated to be eligible for SNAP received benefits, up from 69 percent in 2007. ${ }^{9}$ Again, the percentage in 2011 was probably greater. The increase in the rate at which eligible people received SNAP benefits between 2007 and 2011 was probably a result of two factors: the poor economy (which reduced people's income and caused longer periods of need, prompting more people who were already eligible for the program to apply) and changes in the program's administration, such as greater use of online applications, mail-in renewals, and phone interviews (which have made it easier for people to apply for and continue receiving benefits).

The poorest households were most likely to participate in the program. ${ }^{10}$ Although only 72 percent of people estimated to be eligible for benefits received them in 2009, a much greater percentage, an estimated 91 percent, of the benefits that all eligible people could have received were

8. For participation rates through 2009, see Joshua Leftin, Esa Eslami, and Mark Strayer, Supplemental Nutrition Assistance Program Participation Rates: Fiscal Year 2002 to Fiscal Year 2009 (report submitted by Mathematica Policy Research to the Department of Agriculture, Food and Nutrition Service, Office of Research and Analysis, August 2011), www.fns.usda.gov/ora/ menu/Published/snap/SNAPPartNational.htm.

9. Ibid.

10. Ibid. Among people who are eligible for the program, those in the following groups tend to participate at relatively high rates: households with children, households with income below the federal poverty guideline, and households receiving TANF benefits. Elderly people and those with income above the federal poverty guideline (but still eligible for SNAP) tend to participate at relatively low rates. 
paid out. ${ }^{11}$ Those percentages indicate that eligible households that have lower income (and thus qualify for higher benefits) are more likely to participate in SNAP than eligible households with higher income. (By comparison, in 2001, when the U.S. economy was much stronger, about 65 percent of the benefits for which people were eligible were paid out, researchers estimate.)

\section{Spending}

Outlays for SNAP benefits more than doubled between 2007 and 2011, from about $\$ 30$ billion to $\$ 72$ billion. ${ }^{12}$ Almost two-thirds of the growth in spending on SNAP benefits between 2007 and 2011 stemmed from the increasing number of participants. Over that five-year period, the number of SNAP participants rose by 70 percent, while spending on benefits grew by about 135 percent.

Spending on benefits grew much faster than the number of SNAP participants for several reasons. About 20 percent of that spending growth was directly attributable to changes in SNAP that were enacted in ARRA, which temporarily boosted the maximum benefits by 13.6 percent relative to 2009 amounts and held them at that level until inflation caught up. (Subsequent legislation imposed an earlier expiration date on those higher benefits.) As a result, the maximum benefit in fiscal year 2009 for households with three members increased from $\$ 463$ to $\$ 526$ per month and is scheduled to remain at that amount until the beginning of fiscal year 2014. The remaining increase in total benefits paid was attributable to other factors, such as lower income among beneficiaries and automatic increases in the maximum benefit linked to rising food prices.

\section{Projected SNAP Participation and Spending for 2012 to 2022}

According to CBO's March 2012 baseline projections, almost 34 million people (or about 1 in 10 U.S.

11. Ibid., p. 11 and Appendix D. Leftin, Eslami, and Strayer calculate the participation rates as the ratio of the number of people participating in the program to the number of people eligible for it. The number of participants is based on SNAP administrative data, and the number of eligible people is based on data from the Current Population Survey.

12. In addition to spending on benefits, another $\$ 4$ billion in 2007 and $\$ 6$ billion in 2011 were spent by the federal government on other SNAP-related activities, including program administration, nutrition education, job training, and nutrition assistance for Puerto Rico. residents) will receive SNAP benefits in 2022 if there are no changes in current law. That would be about the same number of people in the program as in 2009 and roughly the same share of the population in the program as in 2008. Spending (mostly for benefits and administrative costs) on SNAP in 2022 will be about $\$ 73$ billion, CBO projects. In inflation-adjusted dollars, spending in 2022 is projected to be about 23 percent less than it was in 2011 but still about 60 percent higher than it was in 2007.

\section{Participation}

The number of people receiving SNAP benefits will begin to slowly decline at the end of fiscal year 2014, $\mathrm{CBO}$ expects, reflecting an improved economic situation and a declining unemployment rate (see Figure 1). Nevertheless, the number of people receiving SNAP benefits will remain high by historical standards, CBO estimates. That is partly because of a growing U.S. population and thus a greater number of potential SNAP participants. $\mathrm{CBO}$ also expects that some of the participants who began to receive benefits during the most recent recession will continue to do so for as long as they are eligible (although the amount of those benefits will be reduced if their income rises). Furthermore, the recent increase in the number of people receiving SNAP benefits means that more people are familiar with the program. Having had previous experience with the program, those people may be more likely to rejoin if they become eligible again. Changes to the administration of SNAP made in recent years also have made it easier for eligible people to participate.

\section{Spending}

Total federal spending on the SNAP program will peak in 2013 at $\$ 82$ billion, CBO estimates, one year before the projected peak in participation. Spending will then gradually fall, CBO projects.

The benefit increase associated with ARRA will end early in fiscal year 2014, leading to a decrease in average perperson benefits from an estimated $\$ 134$ a month in fiscal year 2013 to $\$ 130$ a month in 2014 . Because of that decrease, spending on SNAP is expected to decline in 2014, even though participation is projected to rise slightly. After 2014, the average per-person benefit will rise at an average annual rate of 2.7 percent, $\mathrm{CBO}$ estimates, reaching an estimated \$161 a month in 2022. Nevertheless, with a projected decline in participation, $\mathrm{CBO}$ expects spending to fall by about 9 percent between 2014 and 2022. 


\section{How Does SNAP Work?}

Although federal laws and regulations dictate the basic tenets of SNAP, states can choose from among various policy options to modify the program. As a result, rules affecting eligibility vary among the states. Benefit calculations, however, are generally the same nationwide, as is the maximum benefit that participants can receive. Federal and state governments share administration of the program. A number of policy changes enacted between 1990 and 2011 have significantly affected how the program operates.

\section{Who Is Eligible?}

Eligibility for SNAP is generally based on the participation of household members in other assistance programs or on the income and assets of members of a household. Unauthorized immigrants are not eligible for benefits, and lawfully present noncitizens must meet other specific requirements. ${ }^{13}$

For most households, there is no limit on how long they may participate in SNAP and effectively no work requirement. ${ }^{14}$ Households are typically certified as eligible for the program for periods of 6 to 12 months, depending on their state of residence, sources of income, and other circumstances; the recertification process is roughly the same as the initial application process.

\section{Eligibility Through Participation in Other Programs.} Three-quarters of households receiving SNAP benefits in fiscal year 2010 were considered to be "categorically eligible" - that is, they automatically qualified for those benefits on the basis of their participation in other federal or state programs.

One-third of the categorically eligible households are those in which all members receive cash assistance from TANF, SSI, or some state programs that serve people with low income. The remaining two-thirds of categorically eligible households are those that qualify for benefits under so-called broad-based categorical eligibility. In those households, all members receive or are authorized

13. For details on the eligibility rules for SNAP, see Department of Agriculture, Supplemental Nutrition Assistance Program: Eligibility, www.fns.usda.gov/snap/applicant_recipients/eligibility.htm.

14. However, adults without disabilities who do not have dependent children, are not working or participating in employment-related activities, and are not otherwise exempt are eligible for SNAP benefits for only 3 months in a 36-month period. to receive noncash benefits from TANF (such as child care, transportation assistance, or even a pamphlet or other information describing TANF programs).

Many households that are categorically eligible for benefits are subject to less stringent income and asset criteria than households that are not considered categorically eligible. In fact, most states do not currently have asset limitations for categorically eligible households. Aligning the rules of the SNAP program with those of other programs that provide support to low-income people makes it easier to administer the program and to ensure that eligible households have access to all applicable support programs. ${ }^{15}$

Eligibility Through Income and Asset Tests. Households that are not categorically eligible for SNAP-about onequarter of participating households in fiscal year 2010 can qualify if they meet certain income and asset tests, which are set by law and vary for households with different characteristics. For instance, households in which a member is age 60 or older or disabled generally face different income and asset criteria than other households.

Unless otherwise exempt, households are subject to two income tests, one based on the gross income of the household and another based on its net income. In general, a household's gross income is its total income in the month of application. Net income is calculated as the household's total income in the month of application minus allowable deductions, which can include a portion of the household's earned income and some costs associated with housing and child care, among others. Households that are not categorically eligible can qualify for SNAP benefits only if their gross income is no more than 130 percent of the monthly federal poverty guideline and if their net income is no more than 100 percent of that guideline; for most areas of the country, the guideline applicable in fiscal year 2012 is about $\$ 1,500$ for a household of three and about $\$ 1,900$ for a household of four.

To qualify for SNAP, households that are not categorically eligible for benefits also have to meet an asset test. In

15. For example, see Lindsey J. Leininger and others, The Target Efficiency of Online Medicaid/CHIP Enrollment: An Evaluation of Wisconsin's ACCESS Internet Portal (University of Wisconsin Population Health Institute, State Health Access Reform Evaluation, February 2011), www.shadac.org/blog/share-brief-targetefficiency-wisconsins-access-portal. 
general, households may have no more than $\$ 2,000$ in assets; for households with at least one person who is age 60 or older or is disabled, the asset limit is currently $\$ 3,250$. (Those amounts rise with inflation.) For the purpose of that test, assets include cash, amounts in bank accounts, and other types of financial resources, but they exclude the value of houses, retirement or education savings accounts, and (in most states) cars.

\section{How Are Benefits Calculated and Disbursed?}

Benefit amounts are calculated in the same way for everyone, regardless of how they become eligible. SNAP benefits are based on a household's net income and size. The maximum benefit a household can receive is determined by the number of people in the household and the cost of the Thrifty Food Plan (TFP), a basket of foods selected by the Department of Agriculture (USDA) that would provide a nutritious diet for a household of that size. ${ }^{16}$ (However, because of ARRA, the maximum benefit is set above the cost of the published TFP from April 2009 to October 2013). In fiscal year 2012, for example, the maximum monthly benefit for a household of three in the contiguous United States is $\$ 526$, or about $\$ 5.75$ per person per day; that maximum applies if the household has no net income. Households with income that are receiving SNAP benefits are expected to spend 30 percent of their net income on food. For example, if such a household has net monthly income of $\$ 1,000$, the monthly SNAP benefit in 2012 would be $\$ 226$ $(\$ 526-(0.30 \times \$ 1,000))$, or about $\$ 2.50$ per person per day.

People receive their SNAP benefits through electronic benefit transfer (EBT) cards. Much like a debit card, an EBT card is a plastic card that is replenished electronically each month. (Unlike a debit card, an EBT card cannot be used to withdraw SNAP benefits in cash from an automated teller machine.) In addition to being easier to use and making participation in the program less conspicuous, EBT cards help lessen fraud, misuse of benefits, and errors in benefit payments. ${ }^{17}$

Restrictions limit what items may be purchased with SNAP benefits. Prohibited items include foods hot at the

16. For more information on the Thrifty Food Plan, see Andrea Carlson and others, Thrifty Food Plan, 2006 (Department of Agriculture, Center for Nutrition and Policy Promotion, April 2007), www.cnpp.usda.gov/Publications/FoodPlans/MiscPubs/ TFP2006Report.pdf. point of sale (for example, pizza sold by the slice), alcoholic beverages, cigarettes, vitamins, medicines, and other nonfood items (such as diapers).

\section{How Is the Program Administered and Financed?}

The federal government pays the full cost of SNAP benefits and splits the costs of administering the program about equally with the states. At the federal level, SNAP is managed by the Food and Nutrition Service (FNS), an arm of the Department of Agriculture. In fiscal year 2010, total administrative expenses (state and federal) were about $\$ 7$ billion, just over half of which was used to assess eligibility and recertify people. ${ }^{18}$

For budgetary purposes, SNAP is designated in law as a "mandatory" or "direct spending" program-a category that generally consists of programs that do not receive annual appropriations - even though funds for SNAP are appropriated annually. The amount of money appropriated for the program each year is intended to cover the cost of providing benefits to all people who apply and are eligible. If the appropriated amount does not cover those costs, either lawmakers would need to appropriate additional funds or USDA would have to cut benefits. Although supplemental appropriations were provided about 20 years ago, there has not been any need to use supplemental appropriations or to implement any reduction in benefits in recent years.

\section{How Did Policies Governing SNAP Change Between 1990 and 2011?}

Although economic conditions have a substantial impact on the SNAP caseload, policy changes also have affected the number of people receiving benefits. In 1996, lawmakers enacted the Personal Responsibility and Work Opportunity Reconciliation Act of 1996 (PRWORA, Public Law 104-193), commonly known as welfare reform. That law eliminated SNAP eligibility for many legal immigrants, placed a limit on how long adults

17. Parke Wilde and Margaret Andrews, “The Food Stamp Program in an Era of Welfare Reform: Electronic Benefits and Changing Sources of Cash Income," Journal of Consumer Affairs, vol. 34, no. 1 (Summer 2000), pp. 31-46; and Richard Mantovani and Carol Olander, The Extent of Trafficking in the Food Stamp Program: 2002-2005 (Department of Agriculture, Office of Analysis, Nutrition, and Evaluation, December 2006).

18. Department of Agriculture, Food and Nutrition Service, Program Accountability and Administration Division, Supplemental Nutrition Assistance Program (SNAP) State Activity Report, Federal Fiscal Year 2010 (December 2011), pp. 10-16. 
without disabilities in childless households can receive benefits, and reduced the maximum benefit. The law also replaced a major federal cash entitlement program (AFDC) with a block grant (TANF). Many families who no longer received cash assistance also stopped receiving SNAP benefits, although they were still eligible for the program. ${ }^{19}$

Beginning in the late 1990s, lawmakers began to roll back some of the eligibility restrictions that had been put in place by PRWORA. For example, the Farm Security and Rural Investment Act of 2002 (the 2002 farm bill, P.L. 107-171) relaxed the requirements for participation of legal permanent residents. Changes to federal regulations also allowed states the option to expand categorical eligibility. $^{20}$

Changes in law contributed to the significant rise in the average per-person SNAP benefit over the past several years. The 2002 farm bill and the Food, Conservation, and Energy Act of 2008 (the 2008 farm bill, P.L. 110234) effectively increased benefits through changes in allowable deductions and other aspects of the benefit calculations. Then, as a result of the statutory changes made by ARRA (discussed earlier), the maximum monthly benefit for a household of three rose from $\$ 463$ at the beginning of fiscal year 2009 to $\$ 526$ by the middle of that year.

\section{Approaches to Changing SNAP}

Lawmakers could make changes to the program that would alter future spending. In response to budgetary pressures, the program could be scaled back to help reduce overall federal spending, or it could be expanded to provide more assistance to people and to stimulate the economy in the short term.

19. James P. Ziliak, Craig Gundersen, and David Figlio, "Food Stamp Caseloads Over the Business Cycle," Southern Economic Journal, vol. 69, no. 4 (April 2003), pp. 903-919. Legislative changes to cash assistance programs and SNAP as well as the strong economy at the time contributed significantly to a rapid decline of the SNAP caseload in the late 1990s.

20. See Congressional Budget Office, "The Supplemental Nutrition Assistance Program” (infographic, April 2012).
$\mathrm{CBO}$ has examined four broad sets of options for changing SNAP that policymakers or researchers have identified:

- Changes to the program's rules that could alter the number of people in the program,

- Changes to the program's rules that could modify benefit amounts,

- Changes to the way the program is administered, such as the penalties that are imposed on states that distribute inaccurate amounts of benefits, and

- Changes to the way the program is funded, such as replacing the annual appropriation with a block grant.

\section{Changing Eligibility}

To change spending on SNAP, policymakers could revise the rules for eligibility. Two ways to do that would be to change the requirements for categorical eligibility or to increase or decrease the income or asset requirements; CBO has estimated the budgetary effects of several options of that sort (see Table 2). Also, policymakers could change some of the nonfinancial eligibility criteria; $\mathrm{CBO}$ has analyzed that option qualitatively.

Changing Broad-Based Categorical Eligibility. In fiscal year 2010, about 50 percent of SNAP participants were considered eligible for benefits through their receipt of noncash TANF benefits, so they were not subject to the same income and asset requirements as other participants. ${ }^{21}$ Many people who qualify for SNAP through such broad-based categorical eligibility would remain eligible for SNAP even if they were subject to the income and asset requirements, but some would not. Applying the standard income and asset requirements to people who would otherwise be eligible for benefits through broad-based categorical eligibility would reduce the number of SNAP participants each year by about 1.8 million (or more than 4 percent), on average, over the next 10 years, CBO estimates. Because the participants who would no longer be eligible if subject to those income and asset limits tend to have higher income than other SNAP

21. About 25 percent of SNAP participants were considered eligible for benefits because of their receipt of cash assistance from TANF, SSI, or other similar state programs. Under this policy option, eligibility for those households would not be affected. 
Table 2.

\section{Effects of Selected Policy Options on SNAP Spending and Participation}

\begin{tabular}{|c|c|c|c|c|}
\hline & \multicolumn{2}{|c|}{$\begin{array}{l}\text { Average Change in } \\
\text { Spending per Year, } \\
2013 \text { to } 2022\end{array}$} & \multicolumn{2}{|c|}{$\begin{array}{l}\text { Average Change in Number of } \\
\text { Participants per Year, } \\
2013 \text { to } 2022\end{array}$} \\
\hline & Billions of Dollars & Percent & Millions of People & Percent \\
\hline & \multicolumn{4}{|c|}{ Changing Eligibility } \\
\hline \multicolumn{5}{|l|}{ Changing Broad-Based Categorical Eligibility } \\
\hline $\begin{array}{l}\text { Apply income and asset limits to categorically } \\
\text { eligible households }\end{array}$ & -1.2 & -1.6 & -1.8 & -4.3 \\
\hline \multicolumn{5}{|l|}{ Changing the Gross Income Limit } \\
\hline $\begin{array}{l}\text { Lower the gross income limit to } 100 \text { percent of the } \\
\text { federal poverty guideline in all states }\end{array}$ & -3.2 & -4.1 & -4.2 & -10.2 \\
\hline $\begin{array}{l}\text { Raise the gross income limit to } 200 \text { percent of the } \\
\text { federal poverty guideline in all states }\end{array}$ & 1.0 & 1.3 & 1.9 & 4.6 \\
\hline \multicolumn{4}{|l|}{ Changing the Asset Test } & * \\
\hline & \multicolumn{4}{|c|}{ Changing Benefits } \\
\hline \multicolumn{5}{|l|}{ Changing Maximum Benefits } \\
\hline $\begin{array}{l}\text { Increase the maximum benefit to } 103 \text { percent of the } \\
\text { cost of the Thrifty Food Plan }{ }^{\mathrm{a}}\end{array}$ & 2.3 & 3.0 & * & * \\
\hline $\begin{array}{l}\text { Decrease the maximum benefit to } 97 \text { percent of the } \\
\text { cost of the Thrifty Food Plan }{ }^{\mathrm{a}}\end{array}$ & -2.3 & -3.0 & * & * \\
\hline \multicolumn{5}{|l|}{ Changing Deductions from Income } \\
\hline $\begin{array}{l}\text { Increase the earned income deduction to } 30 \text { percent } \\
\text { Eliminate the automatic deduction for recipients of }\end{array}$ & 2.7 & 3.5 & * & * \\
\hline LIHEAP benefits & -1.5 & -1.9 & * & * \\
\hline
\end{tabular}

Source: Congressional Budget Office.

Notes: Estimates are relative to CBO's March 2012 baseline.

SNAP = Supplemental Nutrition Assistance Program; * = negligible change; LIHEAP = Low Income Home Energy Assistance Program.

a. The maximum benefit a household can receive is based on the cost of the Thrifty Food Plan, a basket of foods selected by the Department of Agriculture that would provide a nutritious diet for a household of that size.

participants, their average benefits are lower, so the resulting savings would be smaller than might otherwise be expected. Eliminating broad-based categorical eligibility would save an average of about $\$ 1.2$ billion per year, which is less than 2 percent of projected spending for the program between 2013 and 2022. In addition, restricting eligibility for SNAP in that way would increase the time required to verify information on SNAP applications, which would probably result in more errors and greater administrative costs.
Changing the Gross Income Limit. Under current law, a household that is not categorically eligible for benefits must have gross income less than or equal to 130 percent of the federal poverty guideline to be eligible for SNAP. If the gross income limit was lowered to 100 percent of the federal poverty guideline for all states, the number of SNAP participants each year would fall by an average of about 10 percent. That reduction in participation would result in savings of about $\$ 3.2$ billion per year, on average, over the next 10 years, or 4 percent of projected 
spending, $\mathrm{CBO}$ estimates. ${ }^{22}$ Again, because the SNAP participants affected would be those with higher income and thus smaller benefits compared with other SNAP participants, the budgetary savings would be smaller (in percentage terms) than the share of participants affected. Alternatively, if the gross income limit was raised to 200 percent of the federal poverty guideline, the number of SNAP participants would rise by almost 5 percent, and the program's cost would climb by about $\$ 1.0$ billion each year, on average, over the next decade, CBO projects. $^{23}$

Changing the Asset Test. Instead of applying the asset test to more households by eliminating broad-based categorical eligibility, policymakers could choose to eliminate the asset test altogether. Doing so would bring in a negligible number of new participants and would increase spending in the program by about $\$ 100$ million a year over the next decade.

Changing Nonfinancial Eligibility Criteria. Policymakers also could change the number of people eligible for SNAP benefits by adjusting nonfinancial eligibility criteria-such as work requirements or the special rules that apply to immigrants, adults without disabilities in childless households, or other groups. Stricter work requirements could lessen spending on the program by reducing the number of participants because of their failure to meet the more stringent requirements or by decreasing benefits for participants who find work and have higher income. Those savings could be partially offset, however, if states increased their SNAP spending on job training to help participants meet the requirements or

22. In making that estimate, $\mathrm{CBO}$ assumed that the net income limit would not change and that the states using broad-based categorical eligibility (under current law) and, consequently, a gross income limit above 130 percent of the federal poverty guideline would be required to use the new 100 percent limit for all SNAP households except those with elderly or disabled members (which are not subject to the gross income limit). However, if those states could continue to use a higher gross income limit through broadbased categorical eligibility, the number of SNAP participants would fall by only 1 percent, and savings would be about $\$ 300$ million per year, in CBO's estimation.

23. $\mathrm{CBO}$ assumed that no other changes would be made to eligibility criteria. For some states currently using broad-based categorical eligibility, the gross income limit is effectively 200 percent of the federal poverty guideline; those states would be unaffected by such a change. increased their spending on processes to verify that recipients are meeting those requirements.

\section{Changing Benefit Amounts}

Rather than changing the number of SNAP beneficiaries, policymakers could alter the spending per beneficiary. Policymakers could adjust benefit amounts for SNAP recipients by changing the maximum benefit or by changing specific components of the benefit formula (see Table 2).

Changing Maximum Benefits. Since PRWORA was enacted, maximum SNAP benefits have been set at 100 percent of the cost of the Thrifty Food Plan.

Policymakers could return maximum benefits to the prePRWORA level of 103 percent of the cost of that plan. Such a change would increase total spending on SNAP by $\$ 2.3$ billion per year, on average, over the next decade, or by about 3 percent of projected spending on benefits. Alternatively, if benefits were reduced from 100 percent to 97 percent of the cost of the TFP, total benefits would decline by similar amounts. Unless the temporary benefit increase put in place by ARRA was also changed, however, this policy would have no effect on benefits until fiscal year 2014.

Changing Deductions from Income. To calculate net income- the income used to determine benefit amounts-households can deduct certain amounts from their total income, including a portion of their earnings and certain expenses for shelter, dependent care, and medical care. One option to boost monthly benefits for a segment of the SNAP population would be to increase the amount of earned income that can be deducted from gross income, thus lowering recipients' net income. Under current law, households with earnings can deduct 20 percent of those earnings from their gross income when determining benefits. If the deduction was raised to 30 percent of earned income, benefits would rise by about $\$ 40$ per month, on average, for those households with earned income, $\mathrm{CBO}$ projects. Overall spending on the program would increase by an average of about $\$ 2.7$ billion per year.

Policymakers also could modify deductions for SNAP benefits by changing how energy assistance payments made through the Low Income Home Energy Assistance Program (LIHEAP) are treated in calculating the deductible amount. Under current law, utility costs and a 
number of other factors are taken into account in determining whether households have excess housing costs that they can deduct. In 2010, about 70 percent of households claimed that deduction for excess housing costs, more than any other deduction besides the standard deduction. ${ }^{24}$

Households qualify for a heating and cooling standard utility allowance (HCSUA), which is typically worth several hundred dollars a month, if they provide proof that they pay heating or cooling expenses or receive assistance through LIHEAP. The number of households claiming the utility allowance through LIHEAP has increased in recent years, in part because some states now send token LIHEAP benefit amounts (typically between $\$ 1$ and $\$ 5$ and typically only once per year) to SNAP participants to automatically qualify them for the allowance. If that automatic qualification was withdrawn and households needed to show proof that they paid heating or cooling expenses, some households would lose their utility allowance and might have their benefits reduced. Instituting such a policy would decrease SNAP benefits by roughly $\$ 90$ per month, on average, for about 1.3 million households and would reduce the program's costs by about $\$ 1.5$ billion each year over the next 10 years, CBO estimates. Eliminating the automatic HCSUA for recipients of such energy assistance would increase the time and effort necessary to collect information about households' utility expenses, however.

\section{Changing Administrative Procedures or Spending for Other Program Activities}

Policymakers also could modify SNAP spending by changing how states are rewarded or penalized for the accuracy of their benefit payments or by adjusting SNAP funding for job training or nutrition education.

\section{Changing the Penalties Imposed on States for Erroneous}

Benefit Payments. A policy that required states to pay a penalty to the federal government for all erroneous payments to SNAP participants-and not just a portion of erroneous payments above some threshold, as under

24. All households are eligible for a deduction from their gross income known as the standard deduction. In fiscal year 2012, the minimum standard deduction is $\$ 147$ for households of one to three people. For larger households, the deduction is 8.3 percent of the income eligibility limit- 130 percent of the federal poverty guideline-for their household size. current policy-would have generated nearly $\$ 2.5$ billion in fiscal year 2010, CBO estimates. (Nationwide, overpayments in fiscal year 2010 totaled an estimated 3 percent of benefit costs, and underpayments totaled less than 1 percent of benefit costs.) In the past several years, the Food and Nutrition Service has assessed a penalty against a few states each year. Those penalties have ranged from $\$ 90,000$ (for New Mexico in 2008) to $\$ 4$ million (for Texas in 2009), depending on the number of beneficiaries in a state and the error rates on its payments. Typically, states may use half of the penalty amounts to improve their administration of SNAP.

Under a policy that required states to pay a penalty equal to their total amount of erroneous payments, every state would need to pay a penalty every year, as it is highly unlikely that a state would make no payment errors. If such a policy had been in place in 2010, the penalties would have been less than $\$ 5$ million for states with relatively small caseloads; for some states with much larger caseloads, however, the penalties would have exceeded $\$ 250$ million. As a share of states' total administrative costs for SNAP, the penalties would have ranged from under 25 percent for some states to more than twice the administrative costs in some other states. Requiring states to pay a penalty equal to all erroneous payments might result in reductions in state staffing for the program, which could cause delays in processing applications, denials for people whose applications might be difficult to accurately process, or other errors.

As an alternative to increasing penalties, lawmakers could increase funds for performance bonus awards for statesnow fixed at $\$ 48$ million per year-to provide a greater incentive to improve the accuracy of their benefit payments.

Changing Spending for Other Program Activities. Current law allows SNAP funds to be spent on certain other activities, apart from providing benefits to participants to purchase food. For example, in fiscal year 2012, about $\$ 100$ million is dedicated to providing education and training to SNAP recipients, and $\$ 388$ million is provided for nutrition education. Policymakers might wish to expand funding for those activities if they believe that additional training or nutrition education would be helpful. Conversely, they might limit funding for those activities if they consider them to be ineffective or outside the scope of the program. 


\section{Changing SNAP to a Block Grant Program}

Converting SNAP to a block grant program, wherein the federal government would allocate set amounts to states, would fundamentally change the way the program is operated. Such a change-which would make SNAP more similar to the TANF program-could transfer much of the decisionmaking power from the federal government to the states, depending on the conditions attached to the grants. For instance, states could be granted the authority to set their own eligibility requirements and benefit amounts and to determine the amounts to be spent for job training or education activities.

Policymakers could decide to allow the amount of the block grant to vary over time or to be fixed in nominal dollars. For example, the amount of the block grant could be indexed to inflation, allowing it to increase over time. Or it could be tied to economic conditions, allowing it to increase during economic downturns and subsequent recoveries and to decrease when the economy was relatively strong. The program's costs would be determined by the structure of the block grant and the amount at which the block grant was set. Under such proposals,
SNAP participants might receive higher or lower benefits than they would receive under current law, depending on how the rules for the block grant were set at the federal and state levels.

This report was prepared by Kathleen FitzGerald and Emily Holcombe of CBO's Budget Analysis Division and Molly Dahl and Jonathan Schwabish of CBO's Health and Human Resources Division. Gregory Acs, formerly of CBO, and Sam Papenfuss provided supervision. Comments were provided by Karen E. Cunnyngham of Mathematica Policy Research; Joe Richardson, formerly of the Congressional Research Service; and James Ziliak of the University of Kentucky. The assistance of external reviewers implies no responsibility for the final product, which rests solely with $\mathrm{CBO}$. This report and other $\mathrm{CBO}$ publications are available at the agency's Web site (www.cbo.gov).

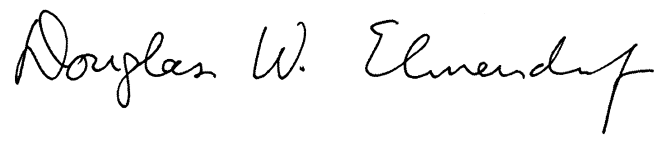

Douglas W. Elmendorf

Director 